\title{
REGIONAL FEATURES OF RURAL UNEMPLOYMENT IN RUSSIA
}

\author{
Elvira Klimentova ${ }^{1}$, Alexander Dubovitski ${ }^{2}$, Elena Yurina ${ }^{3}$, \\ Galina Bayanduryan ${ }^{4}$, Raisa Agabekyan ${ }^{5}$ \\ *Corresponding author E-mail: economresearch@mail.ru
}

A R T I C L E I N F O
Original Article
Received: 08 March 2021
Accepted: 25 May 2021
doi:10.5937/ekoPolj2102357K
UDC 316.334.55:331.56(470)

Keywords:

labor market, employment, unemployment, rural areas, agriculture, state regulation

JEL: J21, J43, J48, J64

\section{A B S T R A C T}

The research is aimed at typologizing the regions of Russia in terms of unemployment with a view to improving regional economic policy. The typology of regions was done using the method of groupings. This enabled the authors to distinguish between rural areas including the level of employment. The authors revealed that the major negative trend in the labor market was the decrease in the number of agriculture jobs, which caused the release of labor and the increased unemployment rates in rural areas. Grouping the regions based on the indicator of employment of the rural population in agricultural sector allowed the authors to identify three types of regions (with high, medium and low unemployment rates) for further use as a criterion for differentiating the state policy of regulating the labor market in rural areas (active and passive).

(C) 2021 EA. All rights reserved.

\section{Introduction}

The need for the formation of sustainable socio-economic systems is an objective necessity for the development of modern society. The vital tasks involve the alleviation of poverty in all its forms and the fight against inequality. Therefore, reducing unemployment is becoming increasingly important. The dramatic changes in the Russian economy in recent years have had a significant impact on all areas, including the functioning of agriculture and rural areas. There has been an increase in

1 Elvira Klimentova, Ph.D., Michurinsk state agrarian University, Michurinsk, Russian Federation, E-mail: economresearch@mail.ru, ORCID ID (https://orcid.org/0000-0001-7628-7181)

2 Alexander Dubovitski, Ph.D., Michurinsk state agrarian University, Michurinsk, Russian Federation, E-mail: daa1-408@yandex.ru, ORCID ID (https://orcid.org/0000-0003-4542-1119)

3 Elena Yurina, Ph.D., G.R. Derzhavin Tambov State University, Tambov, Russian Federation, E-mail: science@tsutmb.ru, ORCID ID (https://orcid.org/0000-0002-1552-1488)

4 Galina Bayanduryan, Ph.D., Kuban State Technological University, Krasnodar, Russian Federation, E-mail: nib.kubstu@gmail.com, ORCID ID (https://orcid.org/0000-0003-2906-5820)

5 Raisa Agabekyan, Ph.D., Academy of marketing and social-information technologies (IMSIT), Krasnodar, Russian Federation, E-mail: info-imsit@mail.ru, ORCID ID (https:// orcid.org/0000-0001-6005-6557) 
the production of crops and livestock. However, this is still not coming close to solving the problem of unemployment.

Rural areas make up a significant part of the natural, demographic and economic potential, and play an important role in the formation and functioning of the labor market of any state. In the Russian Federation, the area of agricultural land constitutes about 400 million hectares (23.4\% of the total territory).

According to the Federal state statistics service of the Russian Federation, 37.6 million people ( $25.6 \%$ of the total population) lived in rural areas in 2018, including 20.1 million people of working age. The Federal state statistics service of the Russian Federation (2020) summed up the results of a sample survey of the labor force, according to which the total number of the unemployed in 2018 accounted for 3.6 million people, while the unemployment rate stood at $4.8 \%$. The number of the unemployed living in rural areas constituted 1.4 million people (37.6\% of the total), and the unemployment rate of the rural population was $8.6 \%$, which is almost twice the average level for the economy (Rosstat, 2020).

At the same time, the results of the HSE research for the centre of Strategic research stated that, "even in the worst times of deep economic downturns, unemployment did not show any signs of "catastrophic growth". According to a survey by the public opinion Foundation, 53\% of Russians assess the unemployment rate as high, $48 \%$ argue that unemployment is growing where they live. Only 8\% notice its decline (Dailymoneyexpert, 2016).

The modern paradigm of the formation of the agrarian economy determines the differentiation of the majority of rural areas according to the degree of economic development and living conditions of the population. This makes it necessary to differentiate rural areas considering the level of employment. This will enable us to develop feasible solutions in the field of regulating the unemployment rates of particular regions, taking into account the individual characteristics of their functioning. These facts prompted the authors to analyze the Russian labor market and evaluate certain regional features in order to justify possible directions of its regulation.

\section{Literature review}

There are different interpretations and approaches to the study of the factors that determine the causes and nature of rural unemployment. There are three main reasons for it: the size of the rural population (Ball et al., 2013); the decline in output (Ilyin et al., 2012); and the level of wages (Krivoschekova, 2016; Smirnova, 2019). The latter explains high rural unemployment by the low quality of vacant jobs (poor working conditions, low pay, delayed wages, lack of prospects, etc.). At the same time, it is noted that the rural labor market is characterized by stagnant unemployment with a high proportion of young people.

The model of interaction between rural and urban labor markets plays an important role in understanding the rural unemployment. Originally it was formulated by Todaro (1969) and further elaborated by Harris \& Todaro (1970). According to this model, 
migration from rural to urban areas correlates with the level of wages in various sectors. Bearing this model in mind, Hicks et al. (2017) showed that there are significant productivity gaps between the agricultural and non-agricultural sectors and examined the implications for sectoral labor redistribution. Ulf et al. (2019) drew conclusions related to the heterogeneity of the wage curve between urban and rural areas, as well as the higher elasticity of unemployment wages in urban areas than in rural areas.

Vakulenko \& Gurvich (2015) created a model describing the relationship between labor productivity, real wages and unemployment on the Russian labor market, and also confirmed that there was a rather high degree of correlation between these factors, which is often observed in other countries.

The Russian labor market is characterized by high intensity and duration of job search (Kylgydai, 2018). Also it is characterized by intensive labor movement between employers, which indicates significant inter-firm mobility (Gimpelson et al., 2016). However, intra-company movements (vertical movement of employees on the intracompany ladder of jobs) is significantly lower (Gimpelson et al., 2014), which suggests a rather low intra-company mobility.

The movement of labor between sectors and regions in Russia is comparatively lower than in other countries (Vakulenko, 2020). This justifies low scale of intersectoral and interregional interaction against considerable spatial dispersion of settlements and low population density. An indirect confirmation of low mobility in Russia is the relatively high inter-regional differences in unemployment rates and wages (Guriev \& Vakulenko, 2015). This fact can be a serious risk factor for the growth of unemployment in certain regions of the country.

According to the research by Koretskaya-Harmash (2016), the growing demand for labor is largely met by migration growth. This process exacerbates the structural imbalance of supply and demand on the Russian labor market (Trotsuk \& Nevzorova, 2015) as a result of the discrepancy between the professional and qualification qualities of applicants to open vacancies (Vasilyeva, 2017). It is obvious that technological development in the near future will reduce the need for the use of unskilled migrant labor, although it may contribute to the growth of unemployment (Grebenyuk, 2020).

The Russian researchers are focused on the social aspects of unemployment. Unemployment is often considered to be one of the major causes of long-term poverty (Sadykov, 2018, Maleva et al., 2020). The authors focus on discriminatory business practices related to individuals of pre-retirement age (Lukyanova \& Kapelyushnikov, 2019, Chernykh et al., 2020) and problems of employment of the young population (Mongush, 2018, Smirnova, 2019), considering them as risks of unemployment.

Researchers address the issue of rural unemployment and its social implications. Rural unemployment is seen in agricultural policy development as an obstacle to improving the well-being of rural communities. For example, Mirzoev (2016), Smirnova, (2019) show the role of agriculture in providing the rural population with employment and 
income. Tatarova (2019) emphasizes the need to subsidize unemployment in agriculture in order to preserve the population and the social structure of rural areas.

Bondarenko \& Tatarova (2019) examined the rural labor market, grouped the territorial entities of Russia and showed the actual inequality of various subjects of the Russian Federation in terms of unemployment. All regions in these studies were divided into three groups based on the indicator "Rural unemployment rate", the authors concluded their apparent differentiation. Indeed, a significant excess of the analyzed indicators over the national average is a sign of a deterioration in the situation on the labor markets of the regions and requires further research as well as practical actions from the state.

\section{Problem statement}

Long-term and heavy rural unemployment in Russia, serious discrepancies in the reasons for the formation of rural unemployment and the socio-economic implications prompted the authors to consider the processes occurring on the Russian labor market as well as assessing certain regional features in order to justify the directions of its regulation.

The hypothesis of the study is based on the assumption that in addition to natural factors of the labor market, there are regional characteristics of rural areas which have a significant impact on rural unemployment. In this paper, the authors attempt to:

- identify the specific features typical of the labor market in rural Russia;

- systematize available analytical data on the causes and patterns of the dynamics of rural unemployment;

- conduct a typology of the territorial differentiation of rural unemployment in the regions and identify certain segments with similar employment parameters;

- justify plausible solutions to the problem of rural unemployment, taking into account the regional characteristics of the rural labor market.

The purpose of this study was to typologize the regions of Russia in terms of unemployment with a view to improving regional economic policy.

\section{Materials and methods}

The authors used statistical and analytical materials of the Federal state statistics service of the Russian Federation, the Ministry of agriculture and the Federal service for labor and employment of the Russian Federation for the period 2005-2018, as well as materials from academic research, scientific conferences and periodicals to assess the condition of rural unemployment in Russia.

The authors used the grouping method to solve the problem of typifying regions for unemployment, which was justified by Rabinovich (1973) and supported in the works of Rakhmankulov \& Gabitov (2009), Chemezova (2013). 
The grouping is based on the system of indicators of labor activity, employment and unemployment, set out in the recommendations of the Resolution concerning statistics of work, employment and labor underutilization, the Ninth International Conference of Labor Statisticians. The authors also relied on the study of Bondarenko \& Tatarova (2019), where the regions of Russia were divided into three groups based on the indicator "Rural unemployment rate".

According to the authors, the grouping should be supplemented with indicators for assessing both the average unemployment rate in the formed groups and the factors affecting it, as well as the peculiarities of the functioning of the rural labor market. Thus, the authors expanded the initial set of features of rural employment and unemployment in the regions based on data published in the statistical collections of the Federal State Statistics Service of Russia.

The grouping feature was the employment rate of the rural population of working age in agricultural production (lea), which allows the authors to trace the impact of the development of agriculture and the availability of jobs on the unemployment rate in rural areas:

$l e^{a}=\frac{e^{a}}{w^{a}} * 100$

where $e^{a}$ - employed in agricultural production; $w^{a}$ - rural population of working age.

The authors identified the following significant features: the share of the rural population in the region; gross agricultural output per 1 rural resident; the general un-employment rate in the region; the unemployment rate in rural areas.

The authors find the value of the interval gap $(h)$ for the given groups based on the maximum $\left(p_{\max }\right)$ and minimum $\left(p_{\min }\right)$ values of the multidimensional average for the distribution of subjects into groups:

$h=\left(p_{\max }-p_{\min }\right) / n$

Further, the authors performed interval sorting of the elements of the group by intervals:

$$
\begin{gathered}
i_{1}=\left(p_{\min } ; p_{\min }+h\right) \\
i_{n}=\left(i_{n-1}+0.1 ; p_{\max }\right)
\end{gathered}
$$

where $n$ - number of intervals; $i=1, \ldots, n$.

The authors grouped regions by intervals in accordance with the average values of the

effective feature $(\bar{Y})$ : 
$\bar{Y}=\frac{\sum_{i=1}^{n} y_{i}}{n}$

where $\mathrm{i}=1, \ldots, \mathrm{n}$.

The authors assume that the statistical population under study consists of $\mathrm{n}$ units (groups) with $\mathrm{k}$ essential features. The authors calculate the arithmetic mean of the attribute for each indicator. The result is a set of average values, the number of which is equal to the number of indicators used for analysis:

$\bar{X}_{1}=\frac{\sum_{i=1}^{n} x_{j 1}}{n}, \bar{X}_{2}=\frac{\sum_{i=1}^{n} x_{j 2}}{n}, \ldots \bar{X}_{k}=\frac{\sum_{i=1}^{n} x_{j k}}{n}$

where $i=1, \ldots, n ; j=1, \ldots, k$.

For practical implementation of this procedure, the authors used the STATISTICA 13.3 application software package.

The authors created a typology of regions based on the employment rate in agricultural production applying the algorithm proposed by Animitsa et al. (2009), as well as the analysis of the results obtained. The potential loss of gross regional product as a result of exceeding the natural unemployment rate is determined by the authors based on the dependence of employment and gross national product (GNP), identified by Okun (1962). The authors justify various options of the state policy for regulating the labor market in relation to different types of regions, taking into account the methods of forecasting economic systems considered in the Ginis (2009) research.

\section{Results and Discussion}

The labor market in rural areas of Russia has specific features related to the location of rural settings and the economic conditions of employment. A significant part of rural settlements function on the basis of the synchronous territorial formation of administrative entities and agricultural production organizations formed in the Soviet period on geographically coinciding territorial spaces. Agriculture in most regions is still the main source of employment for rural people. As a result, the rural economy can be described as multisectoral.

In rural areas, there is a high proportion of workers employed in large agricultural enterprises in the total number of economically active population. This, in turn, causes territorial dispersion and isolation of regional labor markets. As a rule, there is no more than one agricultural enterprise in each setting. If the scale of such firms is reduced or the production activity is discontinued, a significant proportion of the workingage population of such settlements is out of work. Low territorial availability of jobs against low horizontal and vertical mobility complicates the movement of labor. As a result, even if there are no vacancies within this enterprise, there is no free movement 
of employees to other enterprises. People who have lost their jobs end up losing hope of finding them, even if they want to look for them, in other words, they add to the number of economically passive people. According to the authors, the spatial limitation of land resources also affects the formation of the rural labor market. The lack of the chance of additional involvement of land in the production process makes it impossible to ensure a marginal increase in output, and, consequently, the expansion of vacancies within each specific enterprise without changing the technological structure. This makes it difficult to regulate unemployment in rural areas by influencing commodity markets, as mentioned by, for example, Keynes (1936), Kolodziejczak (2018), Piton \& Rycx (2019).

The recovery of the Russian economy in recent decades, accompanied by serious structural changes in the labor market, contributes to the reduction of the rural population (table 1).

Table 1. Labor force, employment and unemployment in rural areas of the Russian Federation, thousand people ${ }^{6}$

\begin{tabular}{|c|c|c|c|c|c|c|}
\hline Indicator & 2005 & 2010 & 2015 & 2016 & 2017 & 2018 \\
\hline Rural population & 38619 & 37772 & 37985 & 37887 & 37772 & 37553 \\
\hline $\begin{array}{l}\text { Rural population of working } \\
\text { age }^{1}\end{array}$ & 22742 & 22218 & 21192 & 20826 & 20507 & 20149 \\
\hline $\begin{array}{l}\text { Persons who are not part of } \\
\text { the labor force }\end{array}$ & 4953 & 5136 & 4648 & 4383 & 4321 & 4449 \\
\hline The labor force & 17789 & 17082 & 16544 & 16443 & 16186 & 15700 \\
\hline $\begin{array}{l}\text { including employed } \\
\text { people }\end{array}$ & 15952 & 15185 & 15158 & 15052 & 14825 & 14350 \\
\hline $\begin{array}{l}\text { some of them } \\
\text { are employed } \\
\text { in agricultural } \\
\text { production }\end{array}$ & 7489 & 6049 & 5507 & 5481 & 5074 & 4936 \\
\hline unemployed & 1836 & 1897 & 1386 & 1391 & 1360 & 1350 \\
\hline $\begin{array}{l}\text { Unemployment rate in rural } \\
\text { areas, } \%\end{array}$ & 10.3 & 11.1 & 8.4 & 8.5 & 8.4 & 8.6 \\
\hline $\begin{array}{l}\text { Employment rate } \\
\text { (employed to working-age } \\
\text { population), } \%\end{array}$ & 70.1 & 68.3 & 71.5 & 72.3 & 72.3 & 71.2 \\
\hline $\begin{array}{l}\text { Level of employment of the } \\
\text { labor force in agriculture, } \%\end{array}$ & 42.1 & 35.4 & 33.3 & 33.3 & 31.3 & 31.4 \\
\hline $\begin{array}{l}\text { The ratio of the unemployed } \\
\text { to the total of those } \\
\text { employed in agriculture and } \\
\text { the unemployed, } \%\end{array}$ & 19.7 & 23.9 & 20.1 & 20.2 & 21.1 & 21.5 \\
\hline
\end{tabular}

Source: compiled by the authors according to Rosstat (2019)

In the period from 2005 to 2018, the rural areas population decreased by 1.1 million people, and the working-age population declined by 2.6 million people, reducing from $59.1 \%$ to $54.6 \%$. According to data, unemployment in rural areas decreased in 2018 to

6 men aged 16-59 years, women-16-54 years 
1.3 million people. The unemployment rate has decreased from $10.3 \%$ to $8.6 \%$ of the active population, but is still well above the optimal level. Unemployment in rural areas is largely stagnant. Half of the unemployed have been looking for work for six months or more, more than a third have been seeking a job for more than a year (Rosstat, 2019).

The decrease in unemployment contributed to an increase in the proportion of people who are not part of the labor force (economically inactive population) from $21.7 \%$ to $22.1 \%$, and their number accounted for about 4.5 million people. According to the data of the Rosstat employment survey (2019), about 1 million people of working age expressed a desire to work. However, according to the ILO methodology, they were not classified as unemployed because they were either not looking for work or were not ready to start work during the survey period. This is the so-called "hidden unemployment".

A negative trend in the labor market is the reduction in jobs in agriculture,the main source of employment in rural areas. The total number of people employed in agricultural production for the period 2005-2018 decreased from 7.5 to 4.9 million people, or by $34 \%$. The employment rate in rural areas decreased from $42.1 \%$ to $31.4 \%$. The release of labor occurs against the background of structural optimization of agricultural production (Babushkin et al., 2021) and growth in labor productivity (Feng et al. (2017), Feng et al. (2018), Bondarenko \& Tatarova (2019), Grebenyuk (2020)).

From 2005 to 2018, the number of large commercial organizations decreased by 2.7 times - from 20.4 to 7.6 thousand. There are processes of bankruptcy and liquidation of inefficient agricultural enterprises. Bankrupt enterprises are taken over by more stable farms, and divisions of large companies are often created on their territory. Every year, the number of jobs eliminated in agricultural organizations significantly exceeds the number created. According to Rosstat (2019), 76.9 thousand jobs were made redundant in 2018 , while only 62.6 thousand jobs were created, which is $22 \%$ less.

The economically active population, released as a result of ongoing processes, migrates in search of work to more prosperous regions, most frequently to urban areas, since individual entrepreneurs and farms are not able to provide enough jobs (Karpunina et al., 2019; Dubovitski \& Klimentova, 2019). Labor migration outside of the place of residence in rural areas during this time increased from 8463 million people to 9413 million people. The level of employment in non - agricultural production increased by 12.4 percent, from $47.6 \%$ to $60.0 \%$. The economically passive population is almost the same as those employed in agricultural production (Fig.1). 
Figure 1. Structural distribution of the working-age rural population, $\%$

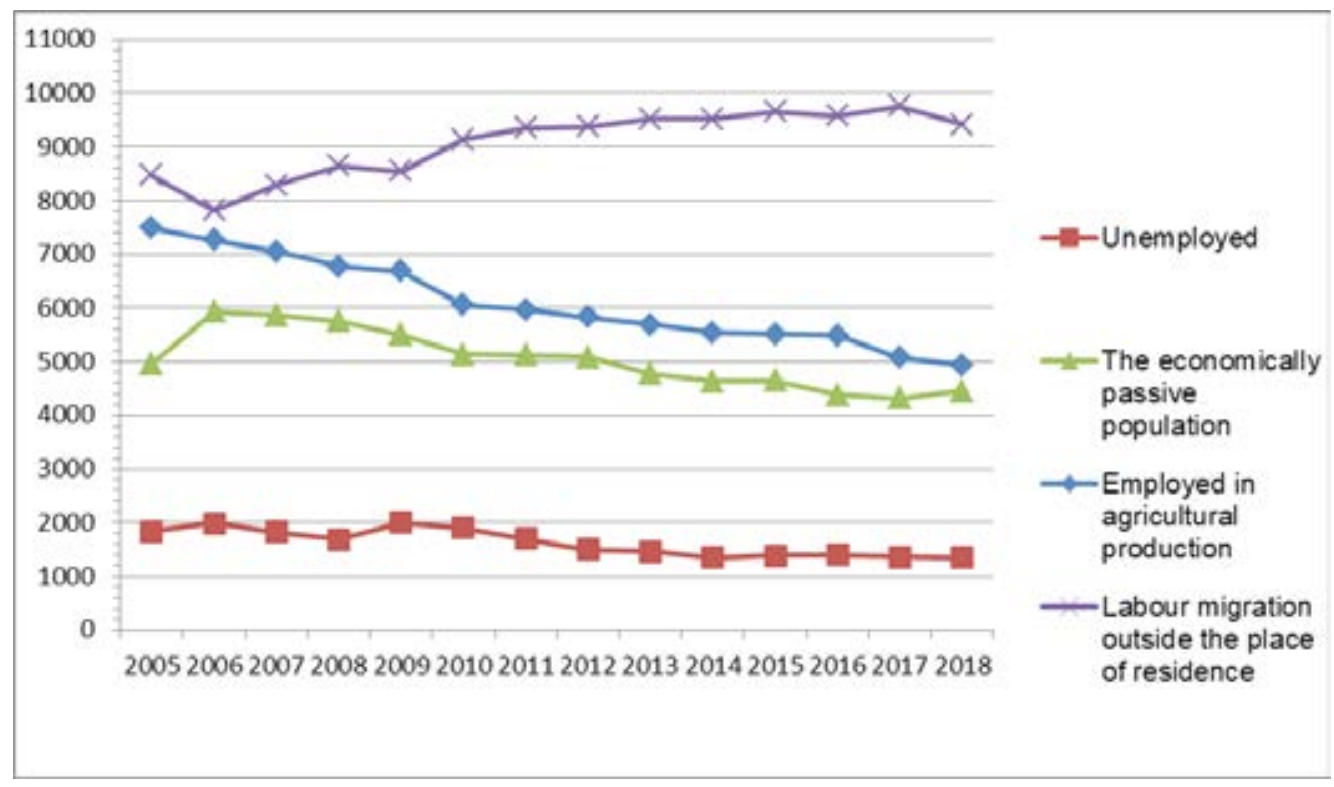

Source: compiled by the authors according to Rosstat (2019)

In our opinion, the lack of vacant jobs within the place of residence creates forced unemployment. The high level of unemployment cannot be explained by an increase in the rural population (Malthus, 1836; Ball et al., 2013) or by a decline in output (Ilyin et al., 2012). This does not happen due to high (Say, 1880; Pigou, 1933) or low level of wages (Vakulenko \& Gurvich, 2015, Krivoschekova, 2016; Smirnova, 2019), although it is lower than the level of industrial sectors in the country, but still slightly increases.

The growth of labor productivity in agriculture reduces the need for the available amount of labor in rural areas. This correlates with the conclusions of Marx (1867) about the additional population compared to the average need for capital.

Lack of work is a crucial factor that determines both high unemployment and the movement of the labor force in the labor market. There is a redistribution of the rural population from the agricultural sector to other sectors under the influence of a narrowing demand for labor from agriculture. In this case, this indicates the limited functionality of the Todaro (1969), Harris \& Todaro (1970) model of labor migration, supported in modern research by Hicks et al. (2017), Ulf et al. (2019), in which migration from rural to urban areas is attributed to differences in wage levels in different regions and sectors.

In these circumstances, only a third of the rural population is provided with work at their place of residence. The supply of labor is three times as much as the demand, which destroys the classical idea of a labor market that operates on the basis of the ratio of supply and demand. In this case, the assumption of Pissarides (2000), which explains unemployment on the labor market as a result of coordination and bargaining between 
firms and workers, does not work. Neither employees nor unions have bargaining power. Firms completely dictate the terms and conditions of employment. This is the decisive factor in determining the level of wages in agriculture, rather than the nature of negotiations (as Blanchard, 2006). In this case, deregulation of the labor market, including the reduction or elimination of the minimum wage (Beck (1999), Blanchard (2006), Freeman (2005), Burgess \& Turon (2010)) can negatively affect unemployment, which poses serious threats to the economy. This is a special case of the development model, when the growth of production in the agricultural sector is not accompanied by an increase in employment in it. In this situation, as shown by Fields (1980), the results of growth in the form of increased income are distributed only among a narrow segment of the population, which leads to increased inequality and social disadvantage in society.

The grouping of regions with the allocation of segments with similar employment parameters enabled the authors to create a typology of the territorial differentiation of rural unemployment in Russia.

The authors chose the level of employment in agricultural production as a grouping feature. The minimum value of the grouping attribute $\left(p_{\min }\right)$ was $4.8 \%$, and the maximum value $\left(p_{\max }\right)$ was $28.0 \%$. For a generalized description of the level of employment, the authors identified three groups. Interval value $(h)$ for specified groups based on $\left(p_{\max }\right)$ and $\left(p_{\text {min }}\right)$ is:

$$
h=\frac{4.8-28.0}{3}=7.7
$$

The intervals were:

$$
\begin{gathered}
i_{1}=(4.8 ; 4.8+7.7=12.5) \\
i_{2}=(12.5+0.1=12.6 ; 12.5+7.7=20.2) \\
i_{3}=(20.2+0.1=20.3 ; 28.0)
\end{gathered}
$$

The average values of the grouping attribute $((\overline{Y)})$ and the aggregate of average values, analyzed indicators $(\bar{X})$ for groups are presented in table 2 . 
Table 2. The grouping of Russian regions on employment of rural population in agricultural production, 2017

\begin{tabular}{|c|c|c|c|c|}
\hline \multirow[t]{2}{*}{ Indicators } & \multicolumn{3}{|c|}{$\begin{array}{c}\text { Groups of regions by the share of } \\
\text { people employed in agricultural } \\
\text { production }\end{array}$} & \multirow{2}{*}{$\begin{array}{l}\text { Average for } \\
\text { the Russian } \\
\text { Federation }\end{array}$} \\
\hline & up to 12.5 & $12.6-20.2$ & $\begin{array}{l}\text { more than } \\
20.3\end{array}$ & \\
\hline Number of regions $^{2}$ & 40 & 33 & 12 & 85 \\
\hline $\begin{array}{l}\text { The share of people employed in agricultural } \\
\text { production in the total rural population of the } \\
\text { region, } \%\end{array}$ & 9.69 & 15.41 & 22.25 & 13.46 \\
\hline $\begin{array}{l}\text { Percentage of rural population in the region, } \\
\%\end{array}$ & 24.05 & 29.76 & 26.41 & 26.54 \\
\hline $\begin{array}{l}\text { Gross agricultural output per } 1 \text { rural resident, } \\
\text { thousand rubles (USD) }\end{array}$ & $\begin{array}{r}100.1 \\
(1540)\end{array}$ & $\begin{array}{r}160.6 \\
(2471)\end{array}$ & $\begin{array}{r}192.5 \\
(2962) \\
\end{array}$ & $\begin{array}{r}135.9 \\
(2091)\end{array}$ \\
\hline Overall unemployment rate in the region, $\%$ & 4.7 & 6.3 & 5.7 & 5.2 \\
\hline The unemployment rate in rural areas, $\%$ & 8.9 & 8.6 & 6.3 & 8.4 \\
\hline
\end{tabular}

Source: compiled by the authors according to Rosstat (2019)

The analysis of Russian regions in terms of employment in agricultural production confirms the dependence of the unemployment rate in rural areas on the development of agriculture and the availability of jobs in it. Higher employment in agriculture correlates with lower unemployment. The first group of regions with a high level of unemployment consists mainly of industrial-type regions and is the most numerous and is characterized by a low share of the rural population engaged in agricultural production (about 10\%). It has the lowest volume of agricultural production per 1 rural resident and the highest level of rural unemployment, which is almost twice as high as the total for these regions. Some of the subjects of this group are highly urbanized territories of the northwestern and central parts of the country, including Moscow, Leningrad, Kaluga, and Tula regions. The other part is the northeastern regions with unfavorable natural and climatic conditions for agriculture, including Tyumen, Tomsk regions, the Komi Republic, Yakutia, Khakassia, etc. The same group includes the regions of the North Caucasus, where the level of employment in agriculture is low, and the unemployment rate is one of the highest - from $13 \%$ to $15 \%$.

The second group with an average level of unemployment involves 33 regions with mixed-type economies, where the average level of employment in agricultural production is about $15 \%$. It includes the subjects with the largest share of the rural population, sufficiently developed industrial and agricultural production, and an average unemployment rate in rural areas of $8.6 \%$. This group includes Oryol, Vologda, Samara, Bryansk, Lipetsk regions, etc.

The third group with low unemployment includes mainly agricultural regions with developed agricultural production. Agricultural production per 1 rural resident is 1.4 times higher than the average in Russia. These are Volgograd, Voronezh, Tambov regions, the Mordovia Republic and a number of others. It has the highest share of 
people employed in agricultural production (22.3\%), and the lowest level of rural unemployment, which does not exceed $6.3 \%$ on average.

In 12 regions of Russia, the rural unemployment rate exceeds $10 \%$, in 6 of them it is higher than $12 \%$, and in 4 it is higher than $14 \%$. The high level of unemployment negatively affects the volume of the gross regional product, preventing it from reaching its potential level. At the same time, the losses are quite significant. The natural unemployment rate in various studies is often assumed to be between 5 and $6 \%$ (Gognac, 2015). Friedman (1968) puts it at 5.5\%. This is consistent with the conclusions of the centre for market research of the national research University Higher school of Economics that the unemployment rate in Russia at 5.8\% is close to natural (RG, 2020).

The authors calculated the excess of the optimal values of the unemployment rate $(\Delta l u)$ based on the actual unemployment rate $\left(l u_{f}\right)$ in certain regions and the natural unemployment rate $\left(l u_{n}\right)$ of $5.8 \%$ :

$\Delta l u=l u_{n}-l u_{f}$

According to the conclusions of Okun (1962), each percentage increase in the level of unemployment above its natural level reduces output by $3.2 \%$ compared to the level that could have been achieved if unemployment had been at the natural level, the potential loss of regional gross product is:

$y=3.2 \Delta l u$

The amount of gross regional product lost in the regions with the highest level of rural unemployment annually ranges from 13.4 to $44.4 \%$ of its actual level. And this problem requires an immediate solution. In addition, employment directly affects the level of poverty of the population. If a third of the economically active population is provided with work, and the rest either do not have work or are forced to leave their place of residence in search of it, it will be impossible to ensure a decent standard of living in rural families in the near future.

According to the authors, the policy of regulating employment in rural areas of Russia should contribute to the fullest use of demographic potential, maintain a balance between supply and demand on the labor market, and improve the standard of living of the rural population. To do this, it is necessary to create institutional, economic and legal conditions for the rational functioning of the rural labor market and the sustainable development of the agricultural economy as the main sphere of employment in rural areas.

Regulation of the labor market is possible through the implementation of measures of passive and active state policy. Passive policies are meant to protect people affected by unemployment. Material support for the unemployed should be socially acceptable while maintaining incentives for active job search. Unfortunately, the country had a relatively low level of compensation for professional and social risks. Most of them are provided for the ILO Convention no. 102 "On minimum standards of social security", 
adopted by the ILO General conference on 28 June 1952 and which Russia has not yet ratified. Starting from January 1, 2019, the minimum allowance was increased to 1,500 rubles (about \$20), and the maximum - to 8,000 rubles (about \$ 114), which is still far from the living standard. Passive policy measures aimed at increasing material support for the unemployed should be implemented in the regions of group 3 with developed agricultural production and low unemployment in rural areas.

A more effective, active employment policy aimed at regulating the level and duration of unemployment is needed in the regions of the 2 nd group with an average unemployment rate and especially the 1 st group with a high unemployment rate. It is aimed at creating conditions for the expansion of agricultural production by various agribusiness entities. The role of agriculture in providing employment in rural areas and rural incomes is proven in the studies of Cejudo et al. (2016), Mirzoev (2016), Ivanov \& Sokolova (2017), Ulf et al. ((2019), Tatarova (2019) for other countries. The creation and preservation of jobs in the agricultural economy should be facilitated by the involvement of unused arable land in production, as well as the expansion of laborintensive industries, such as horticulture and vegetable growing, as well as a number of livestock industries, while meeting the necessary environmental requirements (Dubovitski et al., 2019).

At the same time, the expansion of the rural labor market requires accelerating the pace of rural economic diversification by promoting alternative non-agricultural activities in rural areas, which can take up human resources that do not find a place in the agricultural sector. Special attention should be paid to the development of agricultural processing industries, logistics infrastructure, production of construction materials from local raw materials and woodworking, rural tourism, folk crafts and crafts. It is necessary to use all available opportunities to engage the population in the activities of consumer cooperatives, including harvesting and processing of wild berries, mushrooms, medicinal plants and other natural raw materials. The effectiveness of consumer cooperatives has been proven by the experience of Russian regions (Kostyaev (2018), Pyanova et al. (2019)). However, an economic strategy aimed at stimulating economic growth and employment will be successful by stimulating the expansion of demand for consumer goods. Its dynamics depends fundamentally on the growth of real wages and real household incomes, which is confirmed by the conclusions of Muravyova (2018).

A mechanism to stimulate interest in creating new jobs is needed in regions with high rural unemployment. The authors believe that it is possible to use the concept of creating "free economic zones" with preferential business conditions in rural areas. At the same time, it is necessary to link the volume of state support for agri-business with the number of newly created jobs or with the maintenance of existing ones. It should be beneficial for employers to increase vacancies, rather than make employees redundant. Regarding measures of state support for rural areas, it is advisable to provide credit support for alternative activities of individuals and legal entities that create jobs in this area and register their activities in rural areas, and not only individual subsidiary farms, peasant farms and agricultural consumer cooperatives. A stimulating mechanism for http://ea.bg.ac.rs 
the development of non-agricultural employment in rural areas can be the use of the "tax holidays" mechanism for individual entrepreneurs and organizations registered and engaged in alternative activities in rural areas.

\section{Conclusions}

The authors analyzed the state of rural unemployment in the Russian regions and identified specific features of the rural labor market, including the mono-sectoral nature of the rural economy, the high proportion of workers employed in large agricultural enterprises, the territorial dispersion and isolation of regional labor markets, the low territorial availability of jobs and low horizontal and vertical mobility, the spatial limitations of the main factor of production (land resources).

The authors reveal the main cause of rural unemployment in Russia - the reduction of jobs in agriculture in the context of structural optimization of agricultural production and labor productivity growth. The release of the labor force affects the growth of forced unemployment and migration of the population to more prosperous regions in terms of job availability, most often to urban areas.

The authors typologize the territorial differentiation of rural unemployment in the regions with the allocation of segments with similar employment parameters. The determining influence of the development of agriculture on the level of unemployment in rural areas, the volume of gross output per 1 rural resident is revealed: an increase in the share of people employed in agricultural production in the regions contributes to a decrease in the level of unemployment and a grow in productivity per capita.

The authors argued that the problem of rural unemployment can be solved by implementing consistent economic transformations and taking into account the regional characteristics of the rural labor market. The authors propose two variants of state policy for regulating the labor market in relation to different types of regions: active (aimed at regulating the level and duration of unemployment) and passive (protection and material support for people affected by unemployment).

\section{Conflict of interests}

The authors declare no conflict of interest.

\section{References}

1. Animitsa, P., Novikova, N., \& Khodus, V. (2009). Typology as a method of research of socio-economic development of regions. Proceedings of the Ural state University of Economics, 1(23), 52-59.

2. Babushkin, V., Dubovitski, A., Klimentova, E., Bazarova, T. \& Melekhova, N. (2021). Rural unemployment in Russia: reasons and regulation mechanism. Turismo: Estudos \& Práticas (UERN), 1, 1-10. 
3. Ball, L., De Roux, N. \& Hofstetter, M. (2013). Unemployment in Latin America and the Caribbean. Open Economies Review, Springer, 24(3), 397-424. https://doi. org/10.1007/s11079-012-9248-2

4. Beck, U. (1999). On Insecurity and Redefining Work. Retrieved from www. jobsletter.org.nz/jbl05210.htm (February 15, 2021).

5. Blanchard, O. (2006). European unemployment: the evolution of facts and ideas. Economic Policy, CEPR, CES, MSH, 21(45), 5-59. https://doi.org/10.2139/ ssrn. 825885

6. Bondarenko, L., \& Tatarova, L. (2019). Employment in rural Russia, IOP Conf. Series: Earth and Environmental Science, 274012068, 1-9.

7. Burgess, S., \& Turon, H. (2010). Worker flows, job flows and unemployment in a matching model. European Economic Review, 54(3), 393-408. https://doi. org/10.1016/j.euroecorev.2009.08.009

8. Cejudo, E., Navarro, F., \& Canete, J. (2016). Evolution and territorial distribution of subsidized temporary agricultural workers in Andalusia. Boletin de la asociacion de geografos Espanoles, 72, 117-147. https://doi.org/10.21138/bage.2334

9. Chemezova, E. (2013). Statistical methods in solving applied problems of territory development. Bulletin of NSUU, 4, 153-165 (in Russian).

10. Chernykh, N., Tarasova, A. \& Syrchin, A. (2020). Persons of Pre-Retirement Age in the Labour Market: Employment Problems and Support Measures. Economy of region, 16(4), 1178-1192. https://doi.org/10.17059/ekon.reg.2020-4-12

11. Dailymoneyexpert (2016). Year results and forecasts. Labor market-2017: Work a lot-get a little. Retrieved from http://dailymoneyexpert.ru/how-tomake/2016/12/19/rynok-truda-2017-rabotat-mnogo-poluchat-malo-13871.html (April 30, 2021).

12. Dubovitski, A., Karpunina, E., Klimentova, E., \& Cheremisina, N. (2019). Ecological and economic foundations of effective land use in agriculture: the implementation prospects of food security. Proceedings of the 33rd International Business Information Management Association Conference (IBIMA): Education Excellence and Innovation Management through Vision 2020, Granada, Spain, 2687-2693.

13. Dubovitsky, A., \& Klimentova, E. (2019). Key Guidelines for the Economic Develop-ment of Small Agribusiness. Economy of agricultural and processing enterprises, 12, 89-94 (in Russian).

14. Feng, S., Hu, Y., \& Moffitt, R. (2017). Long run trends in unemployment and labor force participation in urban China. Journal of Comparative Economics, 45(2), 304-324. https://doi.org/10.1016/j.jce.2017.02.004

15. Feng, Y., Lagakos, D., \& Rauch, J. (2018). Unemployment and Development. NBER Working Paper 25171. https://doi.org/10.3386/ w25171 
16. Fields, G. (1980). Poverty. Inequality and Development. University Press, Cambridge.

17. Freeman, R. (2005). Labour market institutions without blinders: The debate over flexibility and labour market performance. International Economic Journal, Korean International Economic Association, 19(2), 129-145. https://doi. org/10.1080/10168730500080675

18. Gimpelson, V., Zhikhareva, O. \& Kapeliushnikov, R. (2014). Job Turnover: What the Russian Statistics Tells Us. Questions of Economics, (7), 93-126. https://doi. org/10.32609/0042-8736-2014-7-93-126

19. Gimpelson, V., Kapeliushnikov, R. \& Sharunina, A. (2016). The pathways we choose: intra - and interfirm transitions. The HSE Economic Journal, 20(2), 201-242.

20. Ginis, L. (2009). Review of scientific forecasting methods. News of the southern Federal University. Technical science, 3 (92), 231-236.

21. Gognac, V. (2015). The natural rate of unemployment: reality or artifact? Human capital, 5(77), 137-143.

22. Grebenyuk A. (2020). The need of the Russian economy for foreign labor resources in the context of the introduction of new technologies. Regional Economy, 16(2), 507-521. https://doi.org/10.17059/2020-2-13

23. Guriev, S. \& Vakulenko, E. (2015). Breaking out of poverty traps: Internal migration and interregional convergence in Russia. Journal of Comparative Economics, 43, 633-649. https://doi.org/10.1016/j.jce.2015.02.002

24. Harris, J., \& Todaro, M. (1970). Migration, Unemployment and Development: A Two-Sector Analysis. The American Economic Review, 60(1), 126-142.

25. Hicks, J., Kleemans, M., Li, N. \& Miguel, E. (2017). Reevaluating Agricultural Productivity Gaps with Longitudinal Microdata. NBER Working Paper, no. 23253.

26. Ilyin, E., Savin, D., \& Konorev, A. (2012). Rural unemployment: state and ways to re-duce it. Bulletin of the Kursk state agricultural Academy, 3, 47-49.

27. Ivanov, B. \& Sokolova, E. (2017). The role of agriculture for income and employment in the Bulgarian rural areas. International Scientific Conference on Strategies for the Agri-Food Sector and Rural Areas - Dilemmas of Development, Poland: JUN 19-21.

28. Karpunina, E., Klimentova, E., \& Dubovitski, A. (2019). Influence of innovative activity of small business on regional economic growth. Proceedings of Southwestern state University. Series: Economics. Sociology. Management, 1(30), 19-29.

29. Keynes, J. (1936). The General Theory of Employment, Interest and Money. Macmillan, London.

30. Kolodziejczak, W. (2018). Decomposition of unemployment in rural population on the basis of main sources of income in 2002-2009 and 2016. International Scientific Conference on Economic Sciences for Agribusiness and Rural Economy Warsaw, Poland: JUN 07-07. https://doi.org/10.22630/ESARE.2018.2.12 
31. Koretskaya-Harmash, V. (2016). The use of migrant labor is a threat or an advantage for the development of the Russian economy. Regional Economy, 12(2), 471-484. https://doi.org/10.17059/2016-2-13

32. Kostyaev, A. (2018). Agricultural cooperation as an institution self-development of rural areas. Fundamental and applied research of the cooperative sector of the economy, 2, 3-15.

33. Krivoschekova, I. (2016). Trends and directions of development of the labor potential of rural areas. Bulletin of the Voronezh state agrarian University, 2(49), 224-228

34. Kylgydai, A. (2018). Assessment of Labor Market Tension in the Regions. Regional Economics: Theory and Practice, 16(4), 640-650. https://doi.org/10.24891/re.16.4.640

35. Lukyanova, A. \& Kapelyushnikov, R. (2019). Pre-retirement and retirement age workers in the Russian labor market: trends in employment realocation. Questions of Economics, 11, 5-34. https://doi.org/10.32609/0042-8736-2019-11-5-34

36. Maleva, T., Grishina, E., \& Burdiak, A. (2020). Chronic poverty: what affects its mass and sharpness? Questions of Economics, 12, 24-40. https://doi. org/10.32609/0042-8736-2020-12-24-40

37. Malthus, T. (1836). Principles of Political Economy. W. Pickering, London.

38. Marx, K. (1867). Das Kapital Kritik der politischen Ökonomie. Verlag von Otto Meisner, Hamburg.

39. Mirzoev, F. (2016). Employment and unemployment in agriculture. Actual science, 2(11), 329-330.

40. Mongush, Sn. (2018). Labor Market of the Republic at the Stage of Transition to Technological Development: Evidence from the Statistical Materials of the Tyva Republic. Regional Economics: Theory and Practice, 16(4), 665-680. https://doi. org/10.24891/re.16.4.665

41. Muravyova, M. (2018). Socio-economic and demographic motivators of the life quality of rural population in the Russian Federation. Journal of Social Sciences Research, 3, 211-214.

42. Okun, A (1962). Potential GNP: Its Measurement and Significance. In American Statistical Association. Proceedings of the Business and Economic Statistics Section of the Political Economy of Prosperity, Washington. Brookings Institution, 132-145.

43. Pigou, A. (1933). The Theory of Unemployment. Macmillan, London.

44. Pissarides, C. (2000). Equilibrium Unemployment Theory. Second edition. Retrieved from https://ua.b-ok.cc/book/1226892/48ce42 (February 15, 2021).

45. Piton, C., \& Rycx, F. (2019). Unemployment Impact of Product and Labor Market Regulation: Evidence from European Countries. IZA Journal of Labor Policy, 9(1), 1-32. https://doi.org/10.2478/izajolp-2019-0006

46. Pyanova, N., Lygina, N., \& Bocharova, M. (2019). Consumers' cooperation as socially oriented system (on the example of consumers' cooperation of Orel region). Scientific Journal of OrelSIET, 1 (29), 44-49. 
47. Rabinovich, P. (1973). Economic analysis by the method of multidimensional groupings. Agricultural Economics, 9, 60-64.

48. Rakhmankulov, I., \& Gabitov, R. (2009). Method of multidimensional groupings for the study of complex economic structures. Bulletin of the Kazan state Institute of Finance and Economics, 4(17), 54-62.

49. RG (2020). Expert: the unemployment Rate in Russia is close to natural. Retrieved from https://rg.ru/2020/06/02/ekspert-uroven-bezraboticy-v-rossii-blizok-kestestvennomu.html (February 15, 2021).

50. Rosstat (2019). Labor and employment in Russia. Stat. collected. Retrieved from https://rosstat.gov.ru/bgd/regl/b19_36/Main.htm (February 15, 2021).

51. Rosstat (2020). Labor market, employment and wages. Retrieved from http:// www.gks.ru/ (February 15, 2021).

52. Sadykov, R. (2018). Poverty in Russia: A Comparative Analysis and the Peculiarities. Regional Economics: Theory and Practice, 16(8), 1494-1505. https://doi.org/10.24891/re.16.8.1494

53. Say, J.B. (1880). A treatise on political economy; or the production, distribution, and consumption of wealth. Translated from the fourth edition of the French, by Prinsep, C. with notes by the translator in 2001. Kitchener. Ontario.

54. Smirnova, T. (2019). Unemployment in rural settlements in Russia: the state and possibilities of solving the problem. The age of science, 19, 62-67.

55. Tatarova, L. (2019). Rural areas of the region: labor market, forecast, employment policy. Economy, labor, management in agriculture, 9, 103-110.

56. Todaro, M. (1969). A model of labor migration and urban unemployment in less developed countries. The American Economic Review, 59, 138-148.

57. Trotsuk, I. \& Nevzorova, N. (2015). Structural imbalances as a key factor of unemployment in the Russian labor market. RUDN Journal of Sociology, (2), 93-103.

58. Ulf, J., Ruud, E., \& Kare, J. (2019). Regional Wage Responsiveness to Unemployment - Rural-Urban Heterogeneity and Policy Implications. Labour England, 33(3), 371-387. https://doi.org/10.1111/labr.12147

59. Vakulenko, E. (2020). Comparative Analysis of Interregional and Intersectoral Mobility in Russia. Economy of region, 16(4), 1193-1207.https://doi.org/10.17059/ ekon.reg.2020-4-13

60. Vakulenko, E., \& Gurvich, E. (2015). Modeling of the mechanisms of the Russian labor market. Economic issues, 11, 5-29. https://doi.org/10.32609/0042-87362015-11-5-29

61. Vasilyeva, A. (2017). The Forecast of Labour Migration, Reproduction of the Population and Economic Development of Russia. Economy of Region, 13(3), 812-826. https://doi.org/10.17059/2017-3-14 